\title{
Characterization of Cord Blood Natural Killer Cells: Implications for Transplantation and Neonatal Infections
}

\author{
JEAN-HUGUES DALLE, JOSÉ MENEZES, ÉRIC WAGNER, MARIE BLAGDON, \\ JOSETTE CHAMPAGNE, MARTIN A. CHAMPAGNE, AND MICHEL DUVAL
}

Laboratory of Immunovirology [J.-H.D., J.M., M.D.] and Division of Pediatric Hematology-Oncology

[J.-H.D., E.W., M.B., J.C., M.A.C., M.D.], Hôpital Sainte-Justine, Montreal, Quebec, Canada, H3T 1 C5

\section{ABSTRACT}

\begin{abstract}
The role of natural killer (NK) cells in hematopoietic stem cell transplantation and in the control of neonatal infections is not yet clear. Donor-versus-recipient NK cell alloreactivity was found to improve outcome in some settings of hematopoietic stem cell transplantation. We hypothesized that the role of NK cells in cord blood (CB) transplantation and neonatal infections may depend on $\mathrm{CB}$ NK cell maturation stage. We therefore analyzed the expression of NK cell differentiation/phenotypic markers in human $\mathrm{CB}$, as well as functional properties of purified CB NK cells. CD8 and CD57 expression was lower in CB than in adult NK cells. However, the expression of other differentiation markers was similar, as was cell surface density of CD56, the percentage of late NK cell precursors, interferon- $\gamma$ production, and the proliferative response of purified NK cells to IL-2. Spontaneous cytotoxic activity of purified CB NK cells against NK-sensitive targets was low but reached adult levels after treatment with IL-15. Expression of perforin and granzyme B was higher in CB NK cells (90 versus $58 \%$ and 86 versus $69 \%$,
\end{abstract}

respectively). intercellular adhesion molecule-1 and CD161 expression was lower in CB. Surprising, fewer CB NK cells expressed L-selectin, a marker of immature NK cells. Taken together, our results suggest that CB NK cells are phenotypically and functionally mature. (Pediatr Res 57: 649-655, 2005)

CB, cord blood

\section{Abbreviations}

Fas-L, Fas ligand

GVHD, graft-versus-host disease

ICAM, intercellular adhesion molecule

IFN, interferon

KIR, killer cell immunoglobulin-like receptors

LFA, leukocyte function-associated antigen

NK, natural killer

PE, phycoerythrin

TRAIL, tumor necrosis factor-related apoptosis-inducing ligand
Natural killer (NK) cells are innate immune lymphocytes defined by their cell surface expression of the CD56 antigen without expression of the CD3 antigen. They display a broad anti-infectious and antitumor cytolytic activity. They can also secrete various cytokines, such as interferon (IFN)- $\gamma$ and other cytokines that regulate the immune response and hematopoiesis (1). Although NK cells play an important role early in the infectious cycle, at a time when specific immunity has not yet fully developed, their role in the defense of the neonate against infection has not been studied (2). It was demonstrated recently that NK cells play an important role in the outcome of clinical HLA-haploidentical hematopoietic stem cell transplantation $(1,3)$. A positive effect of NK cell alloreactivity has also been

Received April 6, 2004; accepted September 2, 2004.

Correspondence: Michel Duval, M.D., Hôpital Sainte-Justine, 3175, chemin de la Côte-Sainte-Catherine, Montréal, Québec, Canada, H3T 1C5; e-mail: michel.duval@umontreal.ca.

This work was supported by the Fondation Charles-Bruneau, the Fonds d'Opération du Centre de Recherche de l'Hôpital Sainte-Justine, and the Canadian Institutes of Health Research. J.H.D. is a Fellow of the Fondation Charles-Bruneau.

DOI: 10.1203/01.PDR.0000156501.55431.20 reported in a series of unrelated hematopoietic stem cell transplantations (4). We, as several other groups, use cord blood (CB) as a source of stem cells in partially HLA-mismatched transplantation with outcomes similar to those observed in HLA-identical bone marrow transplantation (5-9). CB contains a higher percentage of NK cells than adult blood-, bone marrow-, or cytokine-mobilized peripheral blood stem cell grafts (10). It thus is tempting to speculate that neonatal/CB NK cells may play a role in CB transplantation as well as in the control of neonatal infections.

Several markers of NK cell immaturity have been described. Among these is the level of cell-surface expression of CD56. The majority of adult blood NK cells are CD56 ${ }^{\mathrm{dim}}$, whereas a minority $(\sim 10 \%)$ are CD56 $6^{\text {bright }}(11)$. In vitro studies have defined the differentiation stages of NK cell progenitors from bone marrow precursors. From these studies, it was found that terminal maturation leads to cells that resemble phenotypically and functionally the CD56 $6^{\text {bright }} \mathrm{NK}$ cell subset, thus suggesting that $\mathrm{CD}^{2} 6^{\text {bright }}$ cells may be precursors of $\mathrm{CD}^{\mathrm{dim}}$ cells $(12,13)$. This is further supported by the fact that CD56 ${ }^{\mathrm{dim}}$ cells 
harbor the attributes of more differentiated cells, such as the need for higher concentrations of IL-2 to proliferate and a potent cytotoxic function (13-15). Furthermore, the first NK cells that appear in blood after hematopoietic stem cell transplantation are mainly CD56 bright $(16)$. Several other characteristics have been shown to be associated with immaturity or high cell surface density of CD56: low expression of CD8, CD16, and CD57; high expression of CD11c and L-selectin $(11,13,17,18)$; low expression of killer cell immunoglobulinlike receptors (KIR) and high expression of the CD94/NKG2 family of NK cell receptors $(17,19)$; expression of the highaffinity heterotrimeric IL-2 receptor (IL-2R) $\alpha \beta \gamma$; expansion in response to picomolar doses of IL-2; low cytotoxic activity against NK-sensitive targets; and strong production of cytokines, including IFN- $\gamma(11,13-15)$.

Although studies have investigated NK cells derived from CB hematopoietic progenitors after several days of in vitro maturation with various cytokines, data about primary NK cells from $\mathrm{CB}$ are scarce. One recent study reported that the expression of adhesion molecules is reduced on $\mathrm{CD} 56^{\mathrm{dim}} \mathrm{CB}$ NK cells (20). However, this study did not investigate the full range of phenotypic and functional markers of NK cell maturation. In mice, neonatal NK cells express fewer Ly49 receptors than adult NK cells (21). Ly49 receptors are counterparts of human KIR, the expression of which is lower in immature NK cells (17). Cytotoxic activity of fresh unfractionated human CB mononuclear cells against NK-sensitive targets has been demonstrated to be lower than in adult, a feature associated with CD56 $6^{\text {bright }}$ immature cells $(22,23)$. These data suggest that CB NK cells are immature. Such an immaturity may interfere with their potential role in $\mathrm{CB}$ transplantation and neonatal infections.

We thus undertook a study to examine the differentiation stage of fresh $\mathrm{CB}$ NK cells (i.e. without inducing in vitro maturation). To this end, we compared NK cells from CB and adult blood for all of the phenotypic and functional features that have been associated with distinct differentiation stages of human NK cells. We carried out functional studies using purified NK cells to exclude any bystander cell effect. Our data show that CB NK cells display most of the features associated with maturity in current models of NK cell differentiation. In addition, CB NK cells display some unique features, such as high perforin and granzyme B expression and low L-selectin, intercellular adhesion molecule-1 (ICAM-1), and CD161 expression.

\section{METHODS}

Collection of blood samples. $\mathrm{CB}$ samples were harvested in heparinized tubes by umbilical vein puncture after normal delivery of full-term healthy neonates. Informed written consent, as approved by the local Ethics Committee, was obtained from pregnant women before delivery. Adult peripheral blood samples were obtained from healthy volunteer donors after informed written consent.

NK cell purification. Mononuclear cells were isolated by density gradient centrifugation (Ficoll-Hypaque Plus; Amersham Biosciences, Piscataway, NJ). Cells were cryopreserved in 40\% FCS with 10\% DMSO. Thawed cells were resuspended in RPMI 1640 with 10\% FCS, antibiotics, and L-tyrosine. NK cells were purified from mononuclear cells by negative immunoselection using the StemSep Lineage Depletion kit (StemCell Technologies, Vancouver, BC, Canada), according to the manufacturer's instructions. Briefly, mononuclear cells were incubated for 30 min with an antibody cocktail (anti-CD3, anti-CD4, anti-CD14, anti-CD19, anti-CD66b, and anti-glycophorin A), after which the magnetic colloid was added for an additional $30 \mathrm{~min}$. Cells then were passed through a magnetic column for collection of purified cells. More than $97 \%$ of the purified cells were CD3-CD56+, as assessed by flow cytometry (data not shown).

MAB and flow cytometric analysis. Fresh mononuclear cells were stained with anti-CD56-phycoerythrin (PE) or anti-CD56-FITC and anti-CD3peridin-chlorophyll protein (BD Biosciences, Mississauga, ON, Canada) and one of the following MAbs: anti-CD2-FITC, anti-CD8 $\alpha \alpha$-FITC, anti-CD11aFITC, anti-CD11b-PE, anti-CD11c-PE, anti-CD16-FITC, anti-CD25-FITC, anti-CD50-FITC, anti-CD54-PE, anti-CD57-FITC, anti-CD62L-FITC, antiCD94-PE, anti-CD122-PE, anti-CD132-FITC, anti-CD158a-FITC, antiCD158b-FITC, anti-CD161-FITC, anti-tumor necrosis factor-related apoptosis-inducing ligand (TRAIL)-PE (BD Biosciences), anti-CD102-FITC (Serotec, Raleigh, NC), or anti-Fas ligand (Fas-L)-PE (Caltag; Cedarlane Laboratories, Hornby, ON, Canada). For intracellular staining, mononuclear cells were first surface-stained with the same anti-CD3 and anti-CD56 antibodies, permeabilized using the Fix/Perm cell permeabilization kit (BD Biosciences), and then stained with anti-perforin-FITC (BD Biosciences) or anti-granzyme B-PE (Caltag). Cells were subsequently analyzed on a FACScan flow cytometer (BD Biosciences) using the CellQuest software.

${ }^{51} \mathrm{Cr}$ release assay. Cytotoxicity was assessed using a ${ }^{51} \mathrm{Cr}$ release assay (24). Briefly, $10^{6} \mathrm{~K} 562$ target cells were labeled with $100 \mu \mathrm{Ci}$ of $\mathrm{Na}_{2}{ }^{51} \mathrm{CrO}_{4}$ for $45 \mathrm{~min}$ at $37^{\circ} \mathrm{C}$. Mononuclear cells or purified NK cells were washed twice with PBS and resuspended in culture medium. Ten thousand cells were distributed per well in a $100-\mu \mathrm{L}$ volume, with or without $50 \mathrm{ng} / \mathrm{mL}$ IL- 15 (Immunex, Seattle, WA). Effector cells were added in an equal volume for a 10:1 E:T ratio in triplicate and incubated at $37^{\circ} \mathrm{C}$ for $16 \mathrm{~h}$. Supernatants were assessed for ${ }^{51} \mathrm{Cr}$ release using a $\gamma$-counter. Culture medium or $1 \mathrm{M} \mathrm{HCl}$ was added to labeled target cells for calculation of spontaneous or maximum release, respectively. The percentage of specific ${ }^{51} \mathrm{Cr}$ release was calculated as follows: (cpm experimental release - cpm spontaneous release)/(cpm maximal release $-\mathrm{cpm}$ spontaneous release $) \times 100$. The ratio of spontaneous release to maximal release was $<0.2$ in all experiments.

Intracellular cytokine detection. Mononuclear or purified NK cells were incubated $\left(10^{6} / \mathrm{mL}, 6 \mathrm{~h}, 37^{\circ} \mathrm{C}\right)$ in medium with or without phorbol myristate acetate $\left(10^{-9} \mathrm{M}\right)$ and $\mathrm{Ca}^{2+}$ ionophore $(\mathrm{A} 23187,0.1 \mu \mathrm{g} / \mathrm{mL}$; all reagents were from Sigma Chemical Co.-Aldrich, St. Louis, MO). Brefeldin A (Sigma Chemical Co.-Aldrich; $10 \mu \mathrm{g} / \mathrm{mL}$ ) was added during the last $5 \mathrm{~h}$. Cells were fixed and permeabilized using the Fix/Perm cell permeabilization kit (BD Biosciences) for $10 \mathrm{~min}$ at room temperature. Cells then were stained with an anti-IFN- $\gamma$-FITC MAb (BD Biosciences), washed, and analyzed by flow cytometry.

Cell proliferation studies. Mononuclear cells or purified NK cells were labeled with CFSE (Molecular Probes, Eugene, OR) as reported (25) but with minor modifications. Briefly, cells were resuspended at $10^{7} / \mathrm{mL}$ in PBS- $0.1 \%$ BSA and labeled with $2 \mu \mathrm{M}$ CFSE for $10 \mathrm{~min}$ at room temperature in the dark. Cells were washed twice in PBS-0.1\% BSA and once in complete culture medium. Cell recovery and viability, as assessed by trypan blue dye exclusion, were consistently $>95 \%$. Cells then were plated at a concentration of $10^{6} / \mathrm{mL}$ in wells of a 96-well plate and incubated in the absence or presence of IL-2 (2 $\times 10^{6} \mathrm{U} / \mathrm{mg}$ specific activity; Roche, Indianapolis, IN) at $0.1(3 \mathrm{pM}), 1(30$ $\mathrm{pM})$, and $10 \mathrm{UI} / \mathrm{mL}(0.3 \mathrm{nM})$ for $7 \mathrm{~d}$. After incubation, cells were washed three times in PBS and analyzed by flow cytometry.

Definitions and statistical analysis. For flow cytometric studies, lymphocytes were defined as cells that were positive for at least one of the following markers: CD3, CD19, or CD56. NK cells were defined as $\mathrm{CD}^{-}{ }^{-} \mathrm{CD} 56^{+}$cells. The percentage of cells that expressed a marker was described by its median expression on separate experiments from different adult blood or CB samples. Statistical comparison between marker expression was performed using the nonparametric Mann-Whitney test, using GraphPad Prism 3.00 for Windows (GraphPad Software, San Diego, CA). In this setting of multiple comparisons, $\alpha=0.01$ was used as a threshold of significance.

\section{RESULTS}

NK cell precursors and subsets in $\mathrm{CB}$. The percentage of NK cells among lymphocytes was higher in CB than in adult blood (median, 25 versus 16\%, respectively; $p=0.0006$; Fig. $1 A$ ). Conversely, the percentage of NK-T cells (defined as $\mathrm{CD}^{+}{ }^{+} \mathrm{CD} 56^{+}$) was lower among $\mathrm{CB}$ than among adult lymphocytes ( 0.35 versus $1.56 \% ; p=0.01$; Fig. $1 A)$. It was shown previously that the last NK cell precursor, before CD56 acqui- 

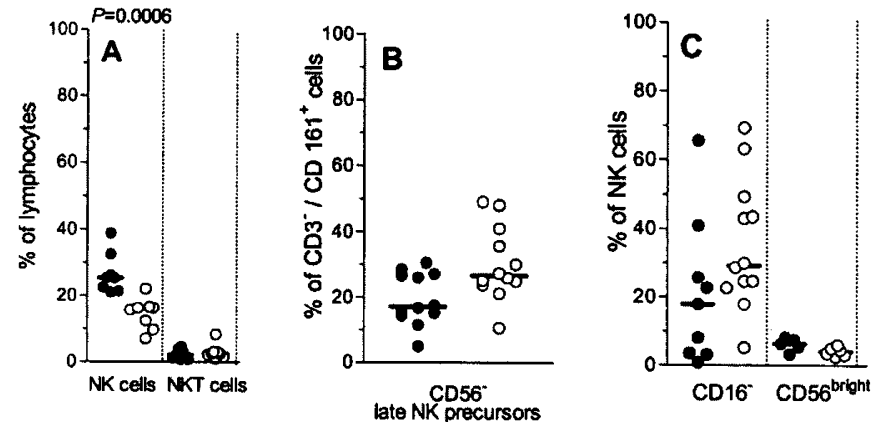

Figure 1. NK cell phenotype and late NK precursors in CB and adult blood. Mononuclear cells from CB (filled circles) and adult blood (open circles) samples were analyzed by flow cytometry. Each symbol represents an individual donor sample. Results are expressed as the percentage and median of each subset. (A) Percentages of NK $\left(\mathrm{CD} 3^{-} \mathrm{CD} 56^{+}\right)$and NK T $\left(\mathrm{CD} 3^{+} \mathrm{CD}^{+} 6^{+}\right)$ cells among lymphocytes were assessed after three-color staining. Lymphocytes were defined as cells expressing CD3 or CD19 or CD56. (B) Percentage of late NK precursors $\left(\mathrm{CD}^{-}{ }^{-} \mathrm{CD} 161^{+} \mathrm{C} 56^{-}\right)$among $\mathrm{CD} 3^{-} \mathrm{CD} 161^{+}$cells was determined after three-color staining. (C) Percentage of CD56 $6^{\text {bright }}$ and CD16 NK cells was determined after two- and three-color staining, respectively.

sition, is the $\mathrm{CD}^{-} \mathrm{CD} 161^{+} \mathrm{CD} 56^{-}$cell (26). We thus compared the percentage of $\mathrm{CD}^{-} \mathrm{CD} 161^{+} \mathrm{CD} 56^{-}$cells among $\mathrm{CD}^{-}{ }^{-} \mathrm{CD} 161^{+}$cells. This percentage of late NK precursors was $17 \%$ in $\mathrm{CB}$ and $27 \%$ in adult blood ( $p=0.06$; Fig. $1 B$ ). $\mathrm{CD} 16^{-}$and $\mathrm{CD} 56^{\text {bright }}$ subsets are thought to be immature $(11,13)$. The percentage of CD56 $6^{\text {bright }}$ cells among NK cells was comparable in $\mathrm{CB}$ and in adult blood (6.3 versus $4 \%$; Fig. 1C). Similarly, the percentage of $\mathrm{CD}^{-} 6^{-}$cells was $18 \%$ among CB and 29\% among adult blood NK cells ( $p=0.08$; Fig. 1C).

We then investigated other features attributed to less differentiated NK cells: no cell surface expression of CD8, CD57, KIR CD158a, and KIR CD158b and cell surface expression of CD11c, L-selectin (CD62L), and CD94 (Fig. 2) (11,13,17-19). There was no difference in the percentage of NK cells that expressed the NK-specific receptors CD94, KIR CD158a, or KIR CD158b or the CD11c surface antigen (Fig. 2). The percentage of NK cells that expressed CD8 and CD57 was lower in $\mathrm{CB}$ than in adult blood [30 versus $62 \%$ for $\mathrm{CD} 8(p=$ $0.009)$ and 10 versus $51 \%$ for $\operatorname{CD} 57(p=0.0003)$; Fig. 2]. However, the percentage of L-selectin-positive NK cells, considered to represent an immature phenotype, was also significantly lower in CB (9.8 versus $23 \%$; $p<0.0001$; Fig. 2).

To have a more complete picture of the phenotypic characteristics of $\mathrm{CB}$ NK cells, we investigated the expression of other activating and adhesion molecules: CD2, LFA- $1 \alpha$ (CD11a), Mac-1 $\alpha$ (CD11b), NKRP-1A (CD161), ICAM-1 (CD54), ICAM-2 (CD102), and ICAM-3 (CD50). The percentage of NK cells that expressed CD2, CD11a, CD11b, ICAM-2, and ICAM-3 was not significantly different among CB an adult blood NK cells (Fig. 2). Fewer CB NK cells expressed ICAM-1 (36.3 versus 99.5\%; $p=0.007$; Fig. 2). CD161, an NK-specific activating molecule, was also expressed by a lower percentage of CB NK cells (1.2 versus $3.9 \% ; p=0.005$; Fig. 2).

$I L-2 R$ expression and proliferation in response to $I L-2$. High-affinity IL-2R $\alpha \beta \gamma$ receptor expression has been associated with a less differentiated NK cell population $(14,15)$. We
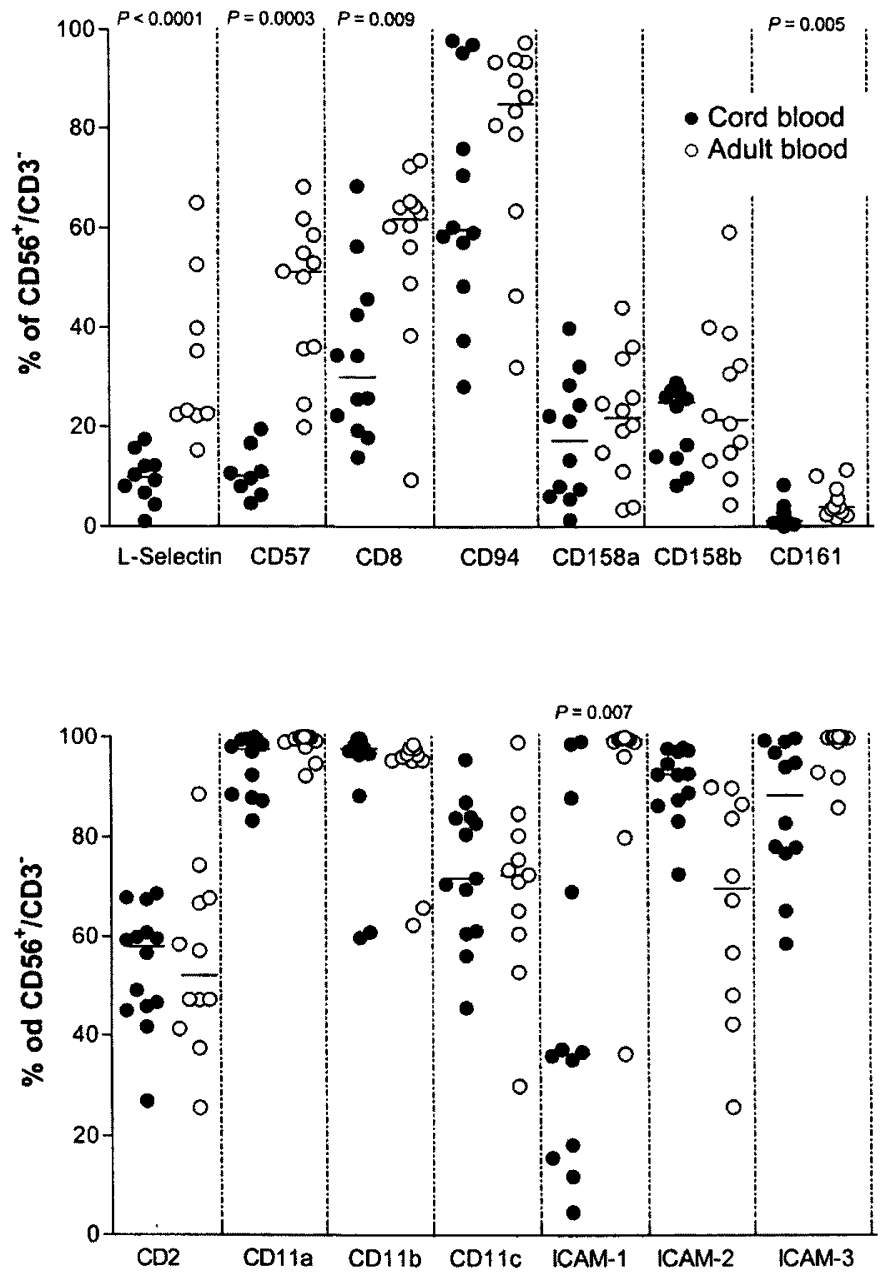

Figure 2. Percentages of NK cells expressing surface proteins associated with different stages of maturation. $\mathrm{CB}$ and adult blood mononuclear cells were analyzed by flow cytometry. Each symbol represents an individual donor sample. Percentages of L-selectin ${ }^{+}\left(\mathrm{CD}_{2} \mathrm{~L}^{+}\right), \mathrm{CD} 57^{+}, \mathrm{CD} 8^{+}, \mathrm{CD} 94^{+}, \mathrm{KIR}$

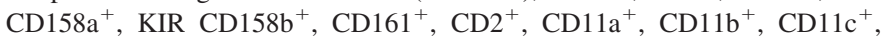
$\mathrm{ICAM}^{-} 1^{+}, \mathrm{ICAM}-2^{+}$, and $\mathrm{ICAM}-3^{+}$cells among $\mathrm{CD} 3^{-} \mathrm{CD}^{+} 6^{+}$cells were determined after three-color staining. Results are expressed as the percentage and median of cells expressing the marker.

thus investigated the expression of IL-2R subunits. IL$2 \mathrm{R} \alpha(\mathrm{CD} 25)$-expressing NK cells were as scarce in $\mathrm{CB}$ as in adult blood (median, 1.7 versus $2.9 \%$; Fig. $3 A$ ). Almost all NK cells expressed IL-2R $\beta$ (CD122) in CB as well as in adult blood. IL-2R $\gamma$ (CD132) was expressed by almost all adult NK cells $(98 \%)$. IL-2R $\gamma$ expression by CB NK cells was highly variable from one individual to another, with a median of $60 \%$ $(p=0.03$; Fig. $3 A)$. Taken together, these results indicate that very few $\mathrm{CB}$ and adult NK cells express the high-affinity IL-2R $\alpha \beta \gamma$ receptor.

Mononuclear cell and NK cell proliferation in the presence of various amounts of IL-2 was assessed by CFSE staining. In agreement with previous studies showing the presence of cells in cycling phase in CB (27), unfractionated CB mononuclear cells proliferated in the absence of IL-2 (data not shown). Response to IL-2 thus was compared between three CB and adult blood samples after purification of NK cells by negative immunomagnetic selection. There was no difference between 

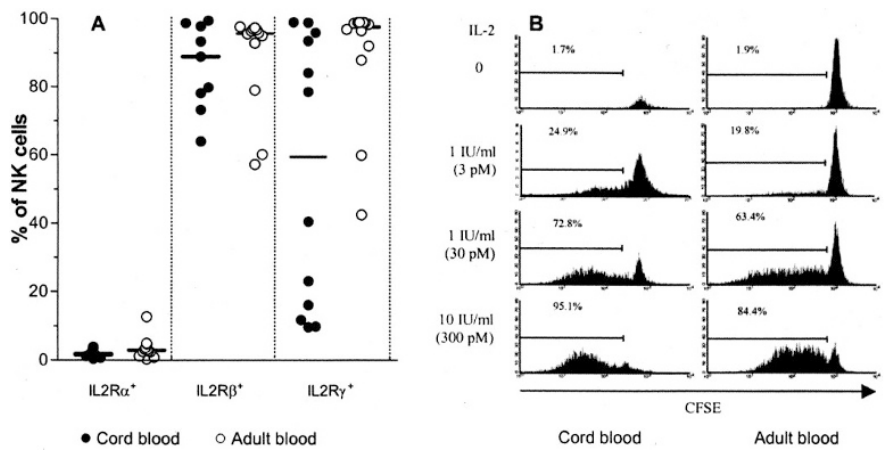

Figure 3. IL-2R expression and proliferative response to IL-2 of CB and adult blood NK cells. (A) CB and adult blood samples were analyzed by flow cytometry. Percentages of CD25 (IL-2R $\alpha)^{+}, \mathrm{CD} 122(\mathrm{IL}-2 \mathrm{R} \beta)^{+}$, and CD132 $(\mathrm{IL}-2 \mathrm{R} \gamma)^{+}$among $\mathrm{CD} 3^{-} \mathrm{CD}^{+} 6^{+}$cells were determined after triple staining. Results are expressed as the percentage and median of positive cells. (B) NK cells that were purified by negative selection were incubated with or without IL-2. NK cells were labeled with CFSE before culture, and CFSE intensity was measured after culture. Results are expressed as percentage of dividing cells, defined as cells having lost initial fluorescence, as determined by unstimulated cultures. Similar results were obtained in three independent experiments.

CB- and adult blood-purified NK cells in their proliferative response to IL-2 (Fig. 3B): NK cells from both adult blood and CB required nanomolar concentrations of IL-2 to proliferate.

Cytotoxicity pathways and cytolytic activity. Lower cytolytic activity is associated with NK cell immaturity (11-13). We determined the percentage of NK cells that expressed molecules associated with different pathways of cytotoxicity by flow cytometry: intracellular granzyme B and perforin, surface Fas-L, and TRAIL. There was no difference between CB and adult blood NK cells for Fas-L and TRAIL expression. However, intracellular granzyme $\mathrm{B}$ and perforin expression was higher in CB NK cells [86 versus $69 \%$ for granzyme B ( $p$ $=0.01)$ and 90 versus $58 \%$ for perforin expression $(p=$ 0.008); Fig. 4A).

Spontaneous cytolytic activity of unfractionated mononuclear cells against K562 targets was lower in CB than in adult blood (Fig. 4B), as already reported (28). We then studied the cytolytic activity of purified NK cells to exclude any effect of
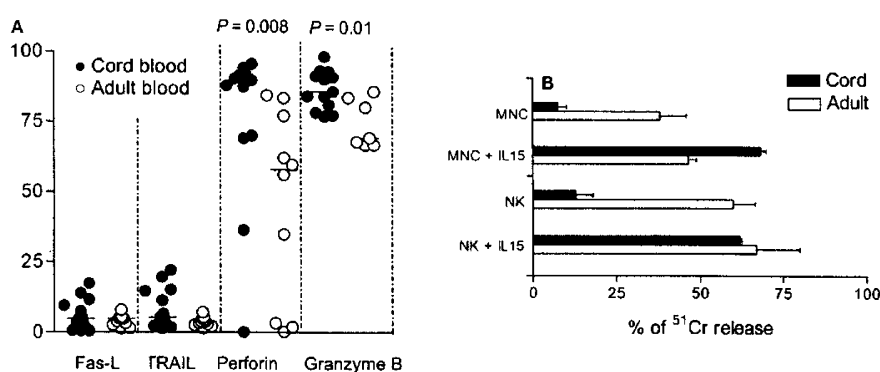

Figure 4. Cytotoxicity-associated proteins and cytolytic activity of $\mathrm{CB}$ and adult blood NK cells. (A) CB and adult blood samples were examined by flow cytometry. Percentages of cell surface Fas-L, TRAIL, and intracellular perforin and granzyme $\mathrm{B}$ in $\mathrm{CD} 3^{-} \mathrm{CD} 56^{+}$cells were assessed by three-color staining. Results are expressed as the percentage and median of positive cells. $(B)$ Unfractionated mononuclear cells (top) and NK cells that were purified by negative selection (bottom) were incubated with or without $50 \mathrm{ng} / \mathrm{mL}$ IL-15. Cytotoxicity against NK-sensitive K562 targets was assessed by ${ }^{51} \mathrm{Cr}$-release assay. Results are expressed as percentage of specific ${ }^{51} \mathrm{Cr}$ release at an effector:target ratio of 10:1 (mean \pm SE of three different samples). bystander cells $(22,23)$. Spontaneous cytotoxicity of purified NK cells against K562 cells was also lower in CB (mean of ${ }^{51} \mathrm{Cr}$ release at E:T ratio 10:1; 13 versus $60 \%$; Fig. $4 B$ ). There was no such difference when the cells were incubated with 50 ng/mL IL-15 (62 versus 67\%; Fig. 4B).

IFN- $\gamma$ production. High IFN- $\gamma$ secretion upon stimulation has also been associated with NK cell immaturity $(11,12)$. The percentage of cells that produced IFN- $\gamma$ upon stimulation with phorbol esters and ionomycin was measured by intracellular staining of unfractionated mononuclear cells and purified NK cells from three adult blood and three CB samples. The percentage of mononuclear cells that produced IFN- $\gamma$ upon stimulation was $11 \%$ in CB versus $20 \%$ in adult blood (Fig. 5). However, the percentage of purified NK cells that produced IFN- $\gamma$ was similar in CB and adult blood (65 versus $77 \%$; Fig. $5)$.

\section{DISCUSSION}

Here, we provide evidence that, unlike their neonatal murine counterparts, human CB NK cells express levels of KIR inhibitory receptors similar to those in adults. CB NK cells display some specific features that differ from adult NK cells, some of which have been associated with a less mature stage of differentiation, i.e. lower expression of CD8 and CD57 cell surface molecules and lower spontaneous cytotoxicity against the NKsensitive K562 target $(11,13,19)$. However, cytotoxicity after incubation with IL-15 was similar, and percentages of NK cells that expressed perforin and granzyme $\mathrm{B}$, proteins that are essential for cytotoxicity, were higher in CB NK cells. Lselectin expression has been associated with immature NK cells $(17,18)$. It is interesting that very few CB NK cells were found to express L-selectin. The percentage of late NK cell precursors $\left(\mathrm{CD}^{-} \mathrm{CD} 161^{+} \mathrm{CD}^{-} 6^{-}\right.$cells) was similar in $\mathrm{CB}$ and adult blood samples. Finally, CB NK cells differed from adult NK cells by their expression of ICAM-1 and CD161. These two molecules were expressed by a lower percentage of $\mathrm{CB}$ NK cells.

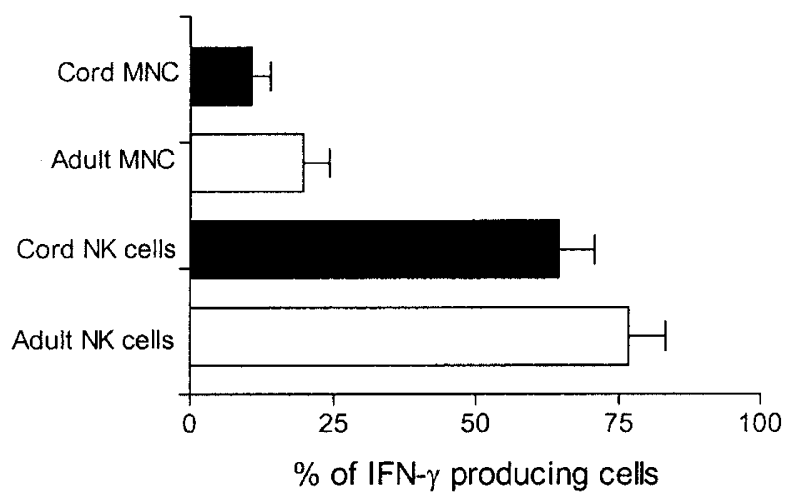

Figure 5. IFN- $\gamma$ production by purified NK cells from adult blood and CB. Unfractionated mononuclear cells and NK cells that were purified by negative selection were incubated for $6 \mathrm{~h}$ with phorbol myristate acetate and $\mathrm{Ca}^{2+}$ ionophore in the presence of brefeldin A. IFN- $\gamma$ production was assessed by flow cytometry after intracellular staining. Results are expressed as the percentage of cells expressing intracellular IFN- $\gamma$ (mean \pm SE of three experiments with different samples). 
In most previous reports, the functional properties of CB NK cells were studied using unfractionated mononuclear cells $(22,23,28)$. The differences between CB and adult blood observed in these reports may not be related to specific properties of CB NK cells but rather to modulation by other cells, such as IL-12- and IL-15-producing monocytes $(22,29)$. Two studies using purified NK cells reported only spontaneous cytotoxicity of $\mathrm{CD}^{-}$cells, $\mathrm{CD} 16^{+} \mathrm{CD} 56^{+}$cells, and $\mathrm{CD} 56^{\mathrm{dim}}$ and CD56 bright subpopulations obtained by positive selection or complement-based negative selection $(20,30)$. To our knowledge, our study is the first to investigate proliferation, IFN- $\gamma$ production, and cytotoxicity of $\mathrm{CB} \mathrm{CD} 3^{-} \mathrm{CD} 56^{+}$cells purified by negative selection. In this study, NK cells were purified by negative immunomagnetic selection to prevent any NK cell activation before experiments were undertaken, and a purity $>97 \%$ was obtained. In agreement with previous reports $(20,22,23,28)$, the spontaneous cytotoxic activity of CB mononuclear cells against NK-sensitive targets is lower than that of adult mononuclear cells. Our data show that the cytolytic activity of purified CB NK cells is also lower, suggesting that the difference in cytotoxic activity against NK-sensitive targets between $\mathrm{CB}$ and adult blood may be attributed to intrinsic differences in NK cells themselves.

This lower cytolytic activity contrasts with a higher percentage of CB NK cells constitutively expressing perforin and granzyme $\mathrm{B}$. It is interesting that cytotoxic activity was rapidly restored by incubation with IL-15, confirming that the cytotoxic potential of CB NK cells is comparable to that of adult NK cells. It has also been reported that enhancement of cytotoxic activity against NK-sensitive targets by IL-12 is more pronounced in CB than in adult mononuclear cells (31). Our data suggest that the lower spontaneous cytotoxic activity of CB NK cells may be related to a lower expression of some adhesion and activating molecules, such as ICAM-1 and CD161, rather than to a defect in the cytotoxic machinery. It has been shown that the percentage of $\mathrm{CD} 16^{+} \mathrm{ICAM}-1^{+}$cells is dramatically increased after culture of $\mathrm{CB}$ but not adult mononuclear cells with IL-12 or IL-15 (32). Taken together, these data suggest that the rapid and dramatic effect of IL-12 and IL-15 on CB NK cell cytotoxicity is associated with an up-regulation of adhesion molecules such as ICAM-1, rather than with cell maturation.

Several hypotheses may explain the few differences noted between CB and adult NK cells. First, CB NK cells may be immature. However, our data show that human CB NK cells display almost all features associated with maturity in current models of NK cell maturation (12). Second, CB NK cells are less likely to have been exposed to immune or inflammatory reactions. Because the production of monocyte-derived cytokines such as IL-12 and IL-15 is decreased in CB, CB NK cells are also less likely to have been exposed to those cytokines $(22,29)$. Third, subsets of NK cells expressing high levels of adhesion and homing molecules such as L-selectin and ICAM-1 may have selectively migrated to the placental or fetal tissues during pregnancy or labor, leaving in the blood stream NK cells with a lower expression of these molecules. Fourth, some subsets of NK cells may expand as a consequence of pregnancy or labor. Particularly, CB NK cells are taken from the placenta, the maternal side of which is characterized by the presence in high numbers of decidual NK cells exhibiting specific properties (33). Exposure to the same cytokines might lead fetal NK cells to share some properties with decidual NK cells. In this regard, it has been reported that decidual NK cells express low levels of L-selectin and display a low level of cytotoxicity against NK-sensitive targets despite normal granzyme B and perforin expression (33). This low cytotoxic activity is restored by incubation with IL-15. (J. Strominger, personal communication).

A previous study showed that the total amount of IFN- $\gamma$ production by mononuclear cells was lower in $\mathrm{CB}$, both spontaneously and after stimulation (22). We have investigated the percentage of cells that are able to produce IFN- $\gamma$ upon stimulation using mononuclear cells as well as purified NK cells. The percentage of IFN- $\gamma$-producing cells was similar among purified NK cells from $\mathrm{CB}$ and adult blood samples, but a lower percentage of $\mathrm{CB}$ unfractionated mononuclear cells produced IFN- $\gamma$ (11 versus $20 \%$ in adults). It has been demonstrated that IFN- $\gamma$ production is decreased in $\mathrm{CB}$ T cells and that the IFN- $\gamma$ promoter is hypermethylated in $\mathrm{CD}^{+} \mathrm{T}$ cells but not in NK CB cells (34). The difference in IFN- $\gamma$ production between $\mathrm{CB}$ and adult blood unfractionated mononuclear cells thus might be due to a lower IFN- $\gamma$ production by CB T cells, not by CB NK cells.

Graft-versus-host disease (GVHD) is less frequent after CB transplantation than after bone marrow or peripheral blood stem cell transplantation (6-9). It has been postulated that this lower rate of GVHD is due to intrinsic features of neonatal $\mathrm{T}$ cells, referred to as $T$ cell immaturity. However, human fetuses are able to mount an adult-like T cell response (35). Similarly, the high rate of engraftment after CB transplantation despite a low stem cell dose is not fully explained. It was shown recently that absence of NK cell inhibition by hematopoietic host cells decreases GVHD rate and improves engraftment in some series of adult stem cell transplantation $(3,4)$. NK cells are the first lymphocytes to recover after $\mathrm{CB}$ transplantation, as early as 1 mo posttransplant (36-38). We show that CB NK cell properties are not strikingly different from those of adult NK cells, supporting the hypothesis that CB NK cells may have a role to play in CB transplantation. Further studies nevertheless are required to fully appreciate the exact role of donor-derived NK cells in CB transplantation.

Neonates are more susceptible to infections than adults, and neonatal infection carries a high risk for fatal outcome. Profound functional impairment has been reported for most of the components of the immune system. Serum complement activity is reduced (39). Polymorphonuclear neutrophil production and chemotaxis is impaired (40). T cells exhibit more frequently a naive phenotype and produce less IL-2, IFN- $\gamma$, and IL-4 (41). Neonatal B cells do not proliferate in response to B cell receptor engagement, and neonates fail to make an antibody response to polysaccharide antigens (41). The production of monocyte-derived cytokines such as IL-12 and IL-15 is decreased in CB $(22,29)$. We showed here that the reduced cytotoxic activity against NK-sensitive targets reported for unfractionated mononuclear cells is also observed after isolation of NK cells. However, normal proliferative potential and 
normal IFN- $\gamma$ production, associated with high expression of perforin and granzyme B, and correction of cytotoxic impairment by treatment with IL-15 suggest that, in contrast with other immune cells, the functional potential of neonatal NK cells is not impaired. Several approaches of immunotherapy have been used in the prophylaxis and treatment of neonatal infections, including i.v. Igs, granulocyte transfusion, and hematopoietic growth factors (42). The clinical benefit of these approaches has not been proved conclusively thus far. Designing new approaches of immunotherapy for neonatal infection may take advantage of the characteristics of neonatal NK cells. We showed earlier that IL-15 plays a predominant role in NK cell activation by Candida albicans, Escherichia coli, Staphylococcus aureus, respiratory syncytial virus, and herpes simplex virus, five pathogens that are involved in neonatal infections $(24,43)$. In light of these data, therapy with IL-15 might be a reasonable approach to treating neonatal infections.

\section{CONCLUSION}

In conclusion, to our knowledge, this is the first study to investigate extensively the phenotypic and functional characteristics of purified CB NK cells. Although the spontaneous cytolytic activity of $\mathrm{CB}$ NK cells in the ${ }^{51} \mathrm{Cr}$ release assay is lower than that of adult NK cells, purified CB NK cells were found to harbor a full potential for cytotoxicity, proliferation, and IFN- $\gamma$ production. Our data do not support the hypothesis that the difference in NK cell characteristics plays a role in the susceptibility of the newborns to infections. Considering their rapid reconstitution after $\mathrm{CB}$ transplantation, our data suggest that $\mathrm{CB}$ NK cells may play a role in the success of $\mathrm{CB}$ transplantation and may be used as effectors in future studies of immunotherapy in CB transplantation and neonatal infections.

Acknowledgments. We thank the Department of Gynecology-Obstetrics of Hôpital Sainte-Justine for kindly providing us with CB samples. We also thank Paulo Cordeiro and R'Kia Dardari for helpful technical support.

\section{REFERENCES}

1. Farag SS, Fehniger TA, Ruggeri L, Velardi A, Caligiuri MA 2002 Natural killer cell receptors: new biology and insights into the graft versus leukemia effect. Blood 100:1935-1948

2. Adkins B, Leclerc C, Marshall-Clarke S 2004 Neonatal adaptive immunity comes of age. Nat Rev Immunol 4:553-564

3. Ruggeri L, Capanni M, Urbani E, Perruccio K, Shlomchik WD, Tosti A, Posati S, Rogaia D, Frassoni F, Aversa F, Martelli MF, Velardi A 2002 Effectiveness of donor natural killer cell alloreactivity in mismatched hematopoietic transplants. Science 295:2097-2100

4. Giebel S, Locatelli FW, Lamparelli T, Velardi A, Davies SM, Frumento G, Maccario R, Bonetti F, Wojnar J, Martinetti M, Frassoni F, Giorgiani G, Bacigalupo A Holowiecki J 2003 Survival advantage with KIR ligand incompatibility in hematopoietic stem cell transplantation from unrelated donors. Blood 102:814-819

5. Dalle JH, Duval M, Moghrabi A, Wagner E, Vachon MF, Barrette S, Bernstein M, Champagne J, David M, Demers J, Rousseau P, Winikoff R, Champagne MA 2004 Results of un unrelated transplant search strategy using partially HLA-mismatched cord blood as an immediate alternative to HLA-matched bone marrow. Bone Marrow Transplant 33:605-611

6. Rocha V, Wagner JE Jr, Sobocinski KA, Klein JP, Zhang MJ, Horowitz MM, Gluckman E 2000 Graft-versus-host disease in children who have received a cordblood or bone marrow transplant from an HLA-identical sibling. Eurocord and International Bone Marrow Transplant Registry Working Committee on Alternative Donor and Stem Cell Sources. N Engl J Med 342:1846-1854

7. Gluckman E, Rocha V, Boyer-Chammard A, Locatelli F, Arcese W, Pasquini R, Ortega J, Souillet G, Ferreira E, Laporte JP, Fernandez M, Chastang C 1997 Outcome of cord-blood transplantation from related and unrelated donors. Eurocord Transplant
Group and the European Blood and Marrow Transplantation Group. N Engl J Med 337:373-381

8. Rubinstein P, Carrier C, Scaradavou A, Kurtzberg J, Adamson J, Migliaccio AR, Berkowitz RL, Cabbad M, Dobrila NL, Taylor PE, Rosenfield RE, Stevens CE 1998 Outcomes among 562 recipients of placental-blood transplants from unrelated donors. N Engl J Med 339:1565-1577

9. Barker JN, Davies SM, DeFor T, Ramsay NK, Weisdorf DJ, Wagner JE 2001 Survival after transplantation of unrelated donor umbilical cord blood is comparable to that of human leukocyte antigen-matched unrelated donor bone marrow: results of a matched-pair analysis. Blood 97:2957-2961

10. Theilgaard-Monch K, Raaschou-Jensen K, Palm H, Schjodt K, Heilmann C, Vindelov L, Jacobsen N, Dickmeiss E 2001 Flow cytometric assessment of lymphocyte subsets, lymphoid progenitors, and hematopoietic stem cells in allogeneic stem cell grafts. Bone Marrow Transplant 28:1073-1082

11. Cooper MA, Fehniger TA, Turner SC, Chen KS, Ghaheri BA, Ghayur T, Carson WE, Caligiuri MA 2001 Human natural killer cells: a unique innate immunoregulatory role for the CD56 $6^{\text {bright }}$ subset. Blood 97:3146-3151

12. Fehniger TA, Caligiuri MA 2001 Ontogeny and expansion of human natural killer cells: clinical implications. Int Rev Immunol 20:503-534

13. Nagler A, Lanier LL, Cwirla S, Phillips JH 1989 Comparative studies of human FcRIII-positive and negative natural killer cells. J Immunol 143:3183-3191

14. Baume DM, Robertson MJ, Levine H, Manley TJ, Schow PW, Ritz J 1992 Differential responses to interleukin 2 define functionally distinct subsets of human natural killer cells. Eur J Immunol 22:1-6

15. Caligiuri MA, Zmuidzinas A, Manley TJ, Levine H, Smith KA, Ritz J 1990 Functional consequences of interleukin 2 receptor expression on resting human lymphocytes. Identification of a novel natural killer cell subset with high affinity receptors. J Exp Med 171:1509-1526

16. Jacobs R, Stoll M, Stratmann G, Leo R, Link H, Schmidt RE 1992 CD16- CD56+ natural killer cells after bone marrow transplantation. Blood 79:3239-3244

17. Andre P, Spertini O, Guia S, Rihet P, Dignat-George F, Brailly H, Sampol J, Anderson PJ, Vivier E 2000 Modification of P-selectin glycoprotein ligand-1 with a natural killer cell-restricted sulfated lactosamine creates an alternate ligand for L-selectin. Proc Natl Acad Sci USA 97:3400-3405

18. Frey M, Packianathan NB, Fehniger TA, Ross ME, Wang WC, Stewart CC, Caligiuri MA, Evans SS 1998 Differential expression and function of L-selectin on CD56 $6^{\text {bright }}$ and CD56 ${ }^{\mathrm{dim}}$ natural killer cell subsets. J Immunol 161:400-408

19. Voss SD, Daley J, Ritz J, Robertson MJ 1998 Participation of the CD94 receptor complex in costimulation of human natural killer cells. J Immunol 160:1618-1626

20. Tanaka H, Kai S, Yamaguchi M, Misawa M, Fujimori Y, Yamamoto M, Hara H 2003 Analysis of natural killer (NK) cell activity and adhesion molecules on NK cells from umbilical cord blood. Eur J Haematol 71:29-38

21. Kubota A, Kubota S, Lohwasser S, Mager DL, Takei F 1999 Diversity of NK cell receptor repertoire in adult and neonatal mice. J Immunol 163:212-216

22. Qian JX, Lee SM, Suen Y, Knoppel E, van de Ven C, Cairo MS 1997 Decreased interleukin-15 from activated cord versus adult peripheral blood mononuclear cells and the effect of interleukin-15 in upregulating antitumor immune activity and cytokine production in cord blood. Blood 90:3106-3117

23. Webb BJ, Bochan MR, Montel A, Padilla LM, Brahmi Z 1994 The lack of NK cytotoxicity associated with fresh HUCB may be due to the presence of soluble HLA in the serum. Cell Immunol 159:246-261

24. Fawaz LM, Sharif-Askari E, Menezes J 1999 Up-regulation of NK cytotoxic activity via IL-15 induction by different viruses: a comparative study. J Immunol 163:44734480

25. Hasbold J, Gett AV, Rush JS, Deenick E, Avery D, Jun J, Hodgkin PD 1999 Quantitative analysis of lymphocyte differentiation and proliferation in vitro using carboxyfluorescein diacetate succinimidyl ester. Immunol Cell Biol 77:516-522

26. Bennett IM, Zatsepina O, Zamai L, Azzoni L, Mikheeva T, Perussia B 1996 Definition of a natural killer NKR-P1A+/CD56-/CD16- functionally immature human NK cell subset that differentiates in vitro in the presence of interleukin 12. J Exp Med 184:1845-1856

27. Leitner A, Strobl H, Fischmeister G, Kurz M, Romanakis K, Haas OA, Printz D, Buchinger P, Bauer S, Gadner H, Fritsch G 1996 Lack of DNA synthesis among CD34+ cells in cord blood and in cytokine-mobilized blood. Br J Haematol 92:255-262

28. Gardiner CM, Meara AO, Reen DJ 1998 Differential cytotoxicity of cord blood and bone marrow-derived natural killer cells. Blood 91:207-213

29. Joyner JL, Augustine NH, Taylor KA, La Pine TR, Hill HR 2000 Effects of group B streptococci on cord and adult mononuclear cell interleukin-12 and interferon-gamma mRNA accumulation and protein secretion. J Infect Dis 182:974-977

30. Sancho L, de la Hera A, Casas J, Vaquer S, Martinez C, Alvarez-Mon M 1991 Two different maturational stages of natural killer lymphocytes in human newborn infants. J Pediatr 119:446-454

31. Lau AS, Sigaroudinia M, Yeung MC, Kohl S 1996 Interleukin-12 induces interferongamma expression and natural killer cytotoxicity in cord blood mononuclear cells. Pediatr Res 39:150-155

32. Lin SJ, Yan DC 2000 ICAM-1 (CD54) expression on T lymphocytes and natural killer cells from umbilical cord blood: regulation with interleukin-12 and interleukin15. Cytokines Cell Mol Ther 6:161-164

33. Koopman LA, Kopcow HD, Rybalov B, Boyson JE, Orange JS, Schatz F, Masch R, Lockwood CJ, Schachter AD, Park PJ, Strominger JL 2003 Human decidual natural killer cells are a unique NK cell subset with immunomodulatory potential. J Exp Med $198: 1201-1212$

34. White GP, Watt PM, Holt BJ, Holt PG 2002 Differential patterns of methylation of the IFN-gamma promoter at $\mathrm{CpG}$ and non-CpG sites underlie differences in IFNgamma gene expression between human neonatal and adult CD45RO- $\mathrm{T}$ cells. J Immunol 168:2820-2827 
35. Hermann E, Truyens C, Alonso-Vega C, Even J, Rodriguez P, Berthe A, GonzalezMerino E, Torrico F, Carlier Y 2002 Human fetuses are able to mount an adultlike CD8 T-cell response. Blood 100:2153-2158

36. Giraud P, Thuret I, Reviron D, Chambost H, Brunet C, Novakovitch G, Farnarier C, Michel G 2000 Immune reconstitution and outcome after unrelated cord blood transplantation: a single paediatric institution experience. Bone Marrow Transplant 25:53-57

37. Thomson BG, Robertson KA, Gowan D, Heilman D, Broxmeyer HE, Emanuel D, Kotylo P, Brahmi Z, Smith FO 2000 Analysis of engraftment, graft-versus-host disease, and immune recovery following unrelated donor cord blood transplantation. Blood 96:2703-2711

38. Klein AK, Patel DD, Gooding ME, Sempowski GD, Chen BJ, Liu C, Kurtzberg J, Haynes BF, Chao NJ 2001 T-Cell recovery in adults and children following umbilical cord blood transplantation. Biol Blood Marrow Transplant 7:454-466
39. Sonntag J, Brandenburg U, Polzehl D, Strauss E, Vogel M, Dudenhausen JW, Obladen M 1998 Complement system in healthy term newborns: reference values in umbilical cord blood. Pediatr Dev Pathol 1:131-135

40. Carr R 2000 Neutrophil production and function in newborn infants. Br J Haemato 110:18-28

41. Marshall-Clarke S, Reen D, Tasker L, Hassan J 2000 Neonatal immunity: how well has it grown up? Immunol Today 21:35-41

42. Suri M, Harrison L, Van de Ven C, Cairo MS 2003 Immunotherapy in the prophylaxis and treatment of neonatal sepsis. Curr Opin Pediatr 15:155-160

43. Tran P, Ahmad R, Xu J, Ahmad A, Menezes J 2003 Host's innate immune response to fungal and bacterial agents in vitro: up-regulation of interleukin-15 gene expression resulting in enhanced natural killer cell activity. Immunology 109:263-270 